\title{
Use of mangrove leaves (Rhizophora mucronath) extract as a biofertilizer for seed germination
}

A. M. Sayekar Habiba, N.B. Yemul ${ }^{1}$ and ${ }^{*}$ R. L. Ghalme

Department of Botany, Dapoli Urban Bank Senior Science College DAPOLI, DIST. RATNAGIRI (M.S.), INDIA

${ }^{1}$ Institute of Science, NAGPUR (M.S.), INDIA

*Corresponding Author Email: rlghalme@gmail.com

Received : 25.03.2020; Accepted : 22.04.2020

\section{ABSTRACT}

The aqueous fresh leaf extract of Rhizophora mucronata Lam. is used for germination of Triticum aestivum (Wheat) and Brassica juncea (Mustard) seeds. The seeds treated with the aqueous extract showed high percentage of germination as well as longer root and shoot length as compared to control and other commercially used biofertilizer like Sargassum treated seeds

Figures : 04

References : 09

Tables : 12

KEY WORDS : Biofertilizer, Longer root, Rhizophora mucronata Lam., Shoot length.

\section{Introduction}

Now-a-Days a number of chemical fertilizers have been used in agriculture at the time of germination to improve crop yield. The applied chemicals increase not only germination percentage but crop yield also. But somehow these substances are responsible for loss of soil fertility and cause threat to herbivores and human health as the toxicants don't wash off from the crop. That's why people are now slowly moving to organic farming and using biofertilizers instead of chemicals. As the biological fertilizers are enriched with all essential nutrients and plant growth regulators (PGRs) so these are used commercially. The commercially used biofertilizers seaweeds (Sargassum, Ulva) were

TABLE-1: Percentage of Wheat Seed Germination in Control

\begin{tabular}{l|c|c|c|c|c}
\hline $\begin{array}{l}\text { Sr. } \\
\text { No. }\end{array}$ & Date & $\begin{array}{c}\text { No. of } \\
\text { germinated } \\
\text { seeds in } \\
\text { Control Set 1 }\end{array}$ & $\begin{array}{c}\text { No. of } \\
\text { germinated } \\
\text { seeds in } \\
\text { Control Set 2 }\end{array}$ & $\begin{array}{c}\text { No. of } \\
\text { germinated } \\
\text { seeds in } \\
\text { Control Set 3 }\end{array}$ & $\begin{array}{c}\% \text { of } \\
\text { germinated }\end{array}$ \\
\hline 1 & $16 / 01 / 20$ & 07 & 07 & 06 & $67 \%$ \\
\hline 2 & $17 / 01 / 20$ & 09 & 09 & 09 & $90 \%$ \\
\hline 3 & $18 / 01 / 20$ & 09 & 09 & 09 & $90 \%$ \\
\hline 4 & $19 / 01 / 20$ & 09 & 09 & 09 & $90 \%$ \\
\hline 5 & $20 / 01 / 20$ & 09 & 09 & 09 & $90 \%$ \\
\hline
\end{tabular}


TABLE-2: Percentage of Wheat Seed Germination in aqueous mangrove leaf extract

\begin{tabular}{l|c|c|c|c|c}
\hline $\begin{array}{c}\text { Sr. } \\
\text { No. }\end{array}$ & Date & $\begin{array}{c}\text { No. of } \\
\text { germinated } \\
\text { seeds in } \\
\text { Mang. 1 }\end{array}$ & $\begin{array}{c}\text { No. of } \\
\text { germinated } \\
\text { seeds in } \\
\text { Mang. 2 }\end{array}$ & $\begin{array}{c}\text { No. of } \\
\text { germinated } \\
\text { seeds in } \\
\text { Mang. 3 }\end{array}$ & $\begin{array}{c}\text { \% of } \\
\text { germinated }\end{array}$ \\
\hline 1 & $16 / 01 / 20$ & 09 & 09 & 09 & $90 \%$ \\
\hline 2 & $17 / 01 / 20$ & 10 & 09 & 09 & $95 \%$ \\
\hline 3 & $18 / 01 / 20$ & 10 & 09 & 09 & $95 \%$ \\
\hline 4 & $19 / 01 / 20$ & 10 & 09 & 09 & $95 \%$ \\
\hline 5 & $20 / 01 / 20$ & 10 & 09 & 09 & 09 \\
\hline
\end{tabular}

TABLE-3: Percentage of Wheat Seed Germination in aqueous algal leaf extract

\begin{tabular}{l|c|c|c|c|c}
\hline $\begin{array}{c}\text { Sr. } \\
\text { No. }\end{array}$ & Date & $\begin{array}{c}\text { No. of } \\
\text { germinated } \\
\text { seeds in } \\
\text { Alg. 1 }\end{array}$ & $\begin{array}{c}\text { No. of } \\
\text { germinated } \\
\text { seeds in } \\
\text { Alg. 2 }\end{array}$ & $\begin{array}{c}\text { No. of } \\
\text { germinated } \\
\text { seeds in } \\
\text { Alg. 3 }\end{array}$ & $\begin{array}{c}\% \text { of } \\
\text { germinated }\end{array}$ \\
\hline 1 & $16 / 01 / 20$ & 10 & 09 & 08 & $90 \%$ \\
\hline 2 & $17 / 01 / 20$ & 10 & 10 & 10 & $100 \%$ \\
\hline 3 & $18 / 01 / 20$ & 10 & 10 & 09 & $97 \%$ \\
\hline 4 & $19 / 01 / 20$ & 10 & 10 & 10 & $100 \%$ \\
\hline 5 & $20 / 01 / 20$ & 10 & 10 & 10 & $100 \%$ \\
\hline
\end{tabular}

TABLE-4: Percentage of Mustard Seed Germination in Control

\begin{tabular}{c|l|c|c}
\hline $\begin{array}{c}\text { Sr. } \\
\text { No }\end{array}$ & Date & $\begin{array}{c}\text { No. of } \\
\text { germinated } \\
\text { seeds in } \\
\text { Control Set }\end{array}$ & $\begin{array}{c}\% \text { of } \\
\text { germination }\end{array}$ \\
\hline 1 & $22 / 01 / 20$ & 07 & $70 \%$ \\
\hline 2 & $23 / 01 / 20$ & 07 & $70 \%$ \\
\hline 3 & $24 / 01 / 20$ & 08 & $80 \%$ \\
\hline 4 & $25 / 01 / 20$ & 08 & $80 \%$ \\
\hline 5 & $26 / 01 / 20$ & 08 & $80 \%$ \\
\hline
\end{tabular}

bryophytes (Anthoceros) and pteridophytes (Azolla).

The mangrove forests are distributed all over the world along coast sides. The mangrove leaves show promising effect on hastening seed germination as it contains Cytokinins such as Zeatin ribosides, Dihydrozeatin, isopentenyl adenine and other molecules ${ }^{3}$. The Gibberellic acid was reported from mangrove leaves ${ }^{4}$. Along the leaf margin an increased Auxin response marked and the high auxin concentration is mediated by the auxin efflux carrier PIN_-FORMEDI which commercially used for Auxin production ${ }^{1}$. The mangrove leaves are used for preparation of Indol 3 Acetic Acid (IAA) and Indol 3 Butyric Acid (IBA).

The mangrove leaf litter is used as biofertilizer for the seed germination in - vitro $^{8}$. 
Use of mangrove leaves (Rhizophora mucronath) extract as a biofertilizer for seed germination

TABLE-5: Percentage of Mustard Seed Germination in Aqueous Mangrove leaf extract

\begin{tabular}{l|c|c|c|c}
\hline $\begin{array}{c}\text { Sr. } \\
\text { No. }\end{array}$ & Date & $\begin{array}{c}\text { No. of germinated } \\
\text { seeds in Mang. 1 }\end{array}$ & $\begin{array}{c}\text { No. of germinated } \\
\text { seeds in Mang. 2 }\end{array}$ & $\begin{array}{c}\text { \% of } \\
\text { germination }\end{array}$ \\
\hline 1 & $22 / 01 / 20$ & 08 & 08 & $80 \%$ \\
\hline 2 & $23 / 01 / 20$ & 08 & 09 & $85 \%$ \\
\hline 3 & $24 / 01 / 20$ & 09 & 09 & $90 \%$ \\
\hline 4 & $25 / 01 / 20$ & 09 & 09 & $90 \%$ \\
\hline 5 & $26 / 01 / 20$ & 09 & 09 & $90 \%$ \\
\hline
\end{tabular}

TABLE-6: Percentage of Mustard Seed Germination in Aqueous Algal extract

\begin{tabular}{l|c|c|c|c}
\hline $\begin{array}{l}\text { Sr. } \\
\text { No. }\end{array}$ & Date & $\begin{array}{c}\text { No. of germinated } \\
\text { seeds in Alg. 1 }\end{array}$ & $\begin{array}{c}\text { No. of germinated } \\
\text { seeds in Alg. 2 }\end{array}$ & $\begin{array}{c}\% \text { of } \\
\text { germination }\end{array}$ \\
\hline 1 & $22 / 01 / 20$ & 05 & 10 & $75 \%$ \\
\hline 2 & $23 / 01 / 20$ & 05 & 10 & $75 \%$ \\
\hline 3 & $24 / 01 / 20$ & 06 & 10 & $80 \%$ \\
\hline 4 & $25 / 01 / 20$ & 06 & 10 & $80 \%$ \\
\hline 5 & $26 / 01 / 20$ & 06 & 10 & $80 \%$ \\
\hline
\end{tabular}

\section{Material and Methods}

Collection of Rhizophora mucronata Leaves and Sargassum (Seaweed):

The mangrove leaves were collected from Jaitapur mangrove forest which is located at $16.59^{\circ} \mathrm{N}$ $73.35^{\circ} \mathrm{E}$ and an average elevation 262.467 feet. It is on the South West coast of Arabian Sea in Ratnagiri district, while the Seaweed Sargassum was collected from shallow water of Ambolgad coast. The village Ambolgad is located at $16.6249^{\circ} \mathrm{N} 73.331^{\circ} \mathrm{E}$ and an average elevation of 52.49 feet.

\section{Perparation of Liquid Biofertilizers} Flow chart for the preparation of $1 \%$ aqueous mangrove leaf Extract:

Fresh leaves were washed thoroughly to remove dust, then surface sterilized by using $70 \%$ ethanol and again washed with water.

Cutting leaf into small pieces excluding midrib

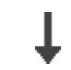

Weighed $1 \mathrm{~g}$ of leaf

$\downarrow$

Hand crushed in morter and pestle and

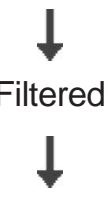

The filtrate was taken and made the final volume upto $100 \mathrm{ml}$ with distilled water. 
TABLE-7: Root Shoot length of grown Wheat Seedlings: Date: 19/01/20

\begin{tabular}{l|c|c|c}
\hline \multirow{2}{*}{ No. } & \multicolumn{2}{|c|}{ Control } & \multirow{2}{*}{ Average } \\
\cline { 2 - 3 } & $\begin{array}{c}\text { Root } \\
\text { Length } \\
\text { (cm) }\end{array}$ & $\begin{array}{c}\text { Shoot } \\
\text { Length } \\
\text { (cm) }\end{array}$ & \\
\hline 1 & 9.1 & 3.4 & 0.373 \\
\hline 2 & 5.0 & 2.6 & 0.52 \\
\hline 3 & 8.0 & 2.7 & 0.337 \\
\hline 4 & 7.1 & 2.2 & 0.309 \\
\hline 5 & 5.2 & 2.4 & 0.461 \\
\hline 6 & 6.4 & 2.5 & 0.390 \\
\hline 7 & 3.4 & 3.0 & 0.882 \\
\hline 8 & 2.2 & 2.5 & 1.13 \\
\hline 9 & 0.5 & 1.2 & 2.4 \\
\hline 10 & - & - & - \\
\hline
\end{tabular}

Flow Chart for the preparation of $1 \%$ aqueous algal leaf Extract:

Fresh Sargassum

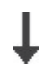

Washed thoroughly with saline water to remove sand then surface sterilized by using ethanol and again washed with water.

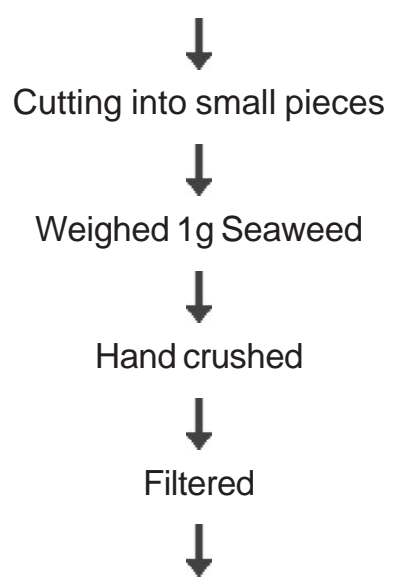

The filtrate was taken and made the final volume upto $100 \mathrm{ml}$ with distilled water.
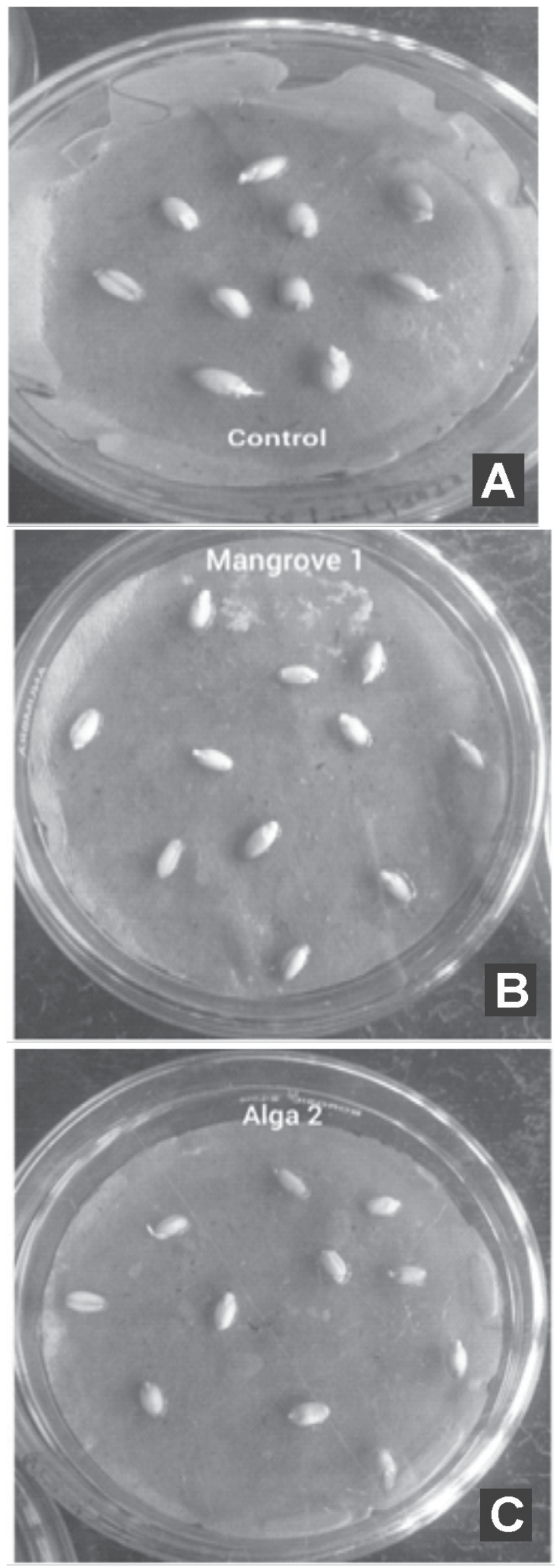

Fig. 1 A-C : Germinating wheat seed 
Use of mangrove leaves (Rhizophora mucronath) extract as a biofertilizer for seed germination

TABLE-8 : Root Shoot length of grown Wheat Seedlings: Date: 19/01/20

\begin{tabular}{l|c|c|c|c|c|c}
\hline Sr. No. & \multicolumn{2}{|c|}{ Mangrove 1 } & Avrg. & \multicolumn{2}{c|}{ Mangrove 2 } & Avrg. \\
\hline & $\begin{array}{c}\text { Root } \\
\text { Length (cm) }\end{array}$ & $\begin{array}{c}\text { Shoot } \\
\text { Length (cm) }\end{array}$ & & $\begin{array}{c}\text { Root } \\
\text { Length (cm) }\end{array}$ & $\begin{array}{c}\text { Shoot } \\
\text { Length(cm) }\end{array}$ & \\
\hline 1 & 8.5 & 3.4 & 0.4 & 9.0 & 3.0 & 0.33 \\
\hline 2 & 10.2 & 3.3 & 0.32 & 8.3 & 3.1 & 0.37 \\
\hline 3 & 7.4 & 3.7 & 0.5 & 10.0 & 3.4 & 0.34 \\
\hline 4 & 6.0 & 3.0 & 0.5 & 6.5 & 2.3 & 0.35 \\
\hline 5 & 6.5 & 3.3 & 0.5 & 6.62 & 2.5 & 0.40 \\
\hline 6 & 8.2 & 3.1 & 0.37 & 5.3 & 2.6 & 0.49 \\
\hline 7 & 6.2 & 2.7 & 0.43 & 6.3 & 3.3 & 0.52 \\
\hline 8 & 6.2 & 2.4 & 0.38 & 4.5 & 2.7 & 0.6 \\
\hline 9 & 6.1 & 3.5 & 0.57 & 4.7 & 2.4 & 0.51 \\
\hline 10 & 4.2 & 2.0 & 0.47 & - & - & - \\
\hline
\end{tabular}

TABLE-9 : Root Shoot length of grown Wheat Seedlings: Date: 19/01/20

\begin{tabular}{l|c|c|c|c|c|c}
\hline Sr. No. & \multicolumn{2}{|c|}{ Algae 1 } & Avrg. & \multicolumn{2}{c|}{ Algae 2 } & Avrg. \\
\hline & $\begin{array}{c}\text { Root } \\
\text { Length (cm) }\end{array}$ & $\begin{array}{c}\text { Shoot } \\
\text { Length (cm) }\end{array}$ & & $\begin{array}{c}\text { Root } \\
\text { Length (cm) }\end{array}$ & $\begin{array}{c}\text { Shoot } \\
\text { Length(cm) }\end{array}$ & \\
\hline 1 & 9.0 & 3.0 & 0.33 & 8.0 & 2.6 & 0.32 \\
\hline 2 & 9.3 & 3.2 & 0.34 & 5.4 & 2.0 & 0.37 \\
\hline 3 & 6.3 & 2.3 & 0.36 & 6.0 & 2.4 & 0.4 \\
\hline 4 & 8.0 & 2.7 & 0.33 & 5.3 & 2.5 & 0.47 \\
\hline 5 & 5.6 & 2.6 & 0.46 & 6.6 & 3.2 & 0.48 \\
\hline 6 & 7.3 & 3.0 & 0.41 & 6.4 & 2.6 & 0.4 \\
\hline 7 & 9.0 & 3.1 & 0.34 & 5.0 & 2.2 & 0.44 \\
\hline 8 & 7.6 & 2.9 & 0.38 & 2.0 & 2.5 & 1.25 \\
\hline 9 & 5.1 & 2.3 & 0.45 & 1.3 & 1.7 & 1.30 \\
\hline 10 & 3.0 & 0.2 & 0.6 & EL:1.2 & - & - \\
\hline
\end{tabular}


TABLE-10: Root Shoot length of grown Mustard Seedlings: Date: 26/01/20

\begin{tabular}{l|c|c|c}
\hline \multirow{2}{*}{ No. } & \multicolumn{2}{|c|}{ Control } & \multirow{2}{*}{ Average } \\
\cline { 2 - 3 } & $\begin{array}{c}\text { Root } \\
\text { Length } \\
\text { (cm) }\end{array}$ & $\begin{array}{c}\text { Shoot } \\
\text { Length } \\
\text { (cm) }\end{array}$ & \\
\hline 1 & 7.9 & 3.7 & 0.46 \\
\hline 2 & 4.9 & 3.1 & 0.63 \\
\hline 3 & 5.0 & 3.0 & 0.6 \\
\hline 4 & 3.3 & 3.0 & 0.9 \\
\hline 5 & 3.1 & 3.0 & 0.96 \\
\hline 6 & 5.5 & 2.3 & 0.41 \\
\hline 7 & 7.5 & 3.5 & 0.46 \\
\hline 8 & 0.5 & 1.0 & 2.0 \\
\hline 9 & - & - & - \\
\hline 10 & - & - & - \\
\hline
\end{tabular}

\section{Crop Selection :}

The crop plants selected for this study were Wheat (Triticum aestivum) and Mustard (Brassica juncea) which belong to plant family Poaceae and Brassicaceae respectively and these are cultivated throughout Indian subcontinent. The seeds for the current study were collected from Agro consultancy in Rajapur. Healthy seeds were selected for the purpose of seed germination assay.

\section{Preparation of Experimental sets :}

The control and experimental sets were prepared in triplets. Control sets were treated with water while experimental sets were treated with aqueous mangrove leaf extract and aqueous algal extract. Each set was containing 10 viable seeds. The little amount of water and above mentioned fertilizers were added to the sets as per the need. The photoperiod of 5-6 hours were given to each set by exposing to sunlight. The sets were observed daily and seed germination along with root shoot length reading were noted to measure growth rate ${ }^{2,9}$.
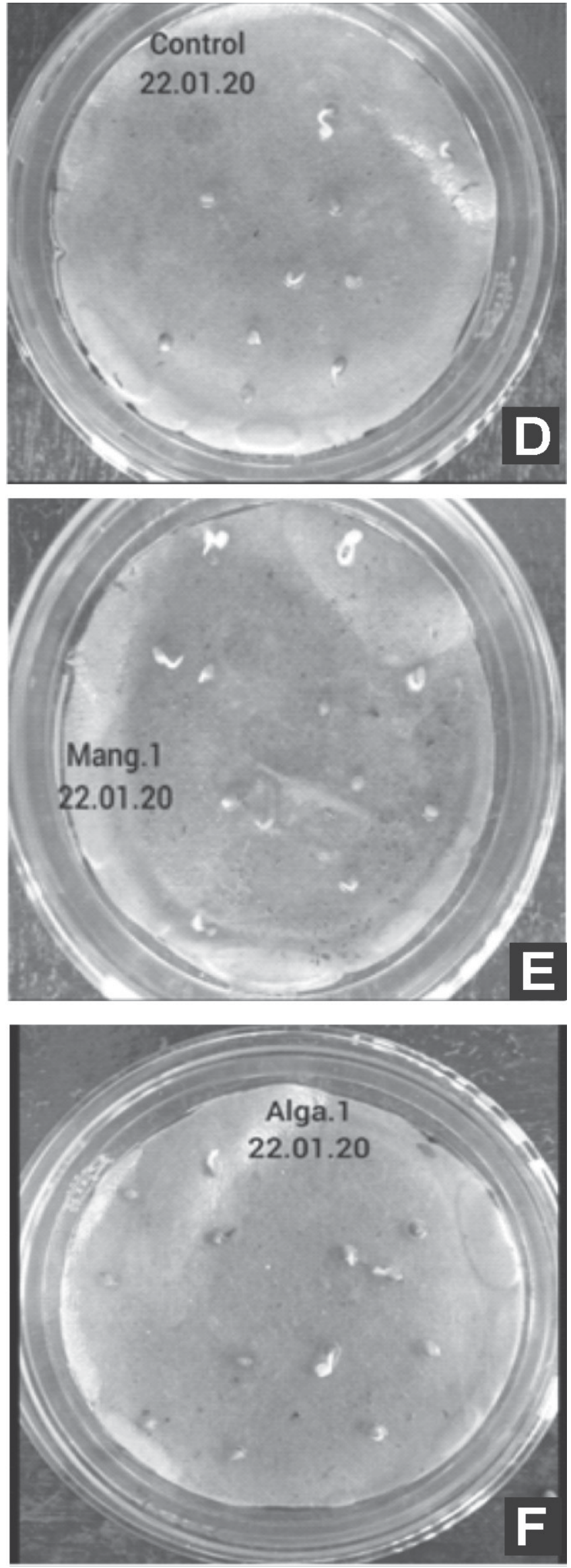

Fig. 2 D-F : Germinating mustard seeds. 
TABLE-11 : Root Shoot length of grown Mustard Seedlings: Date: 26/01/20

\begin{tabular}{|c|c|c|c|c|c|c|}
\hline \multirow[t]{2}{*}{ Sr. No. } & \multicolumn{2}{|c|}{ Mangrove 1} & \multirow[t]{2}{*}{ Avrg. } & \multicolumn{2}{|c|}{ Mangrove 2} & \multirow[t]{2}{*}{ Avrg } \\
\hline & $\begin{array}{c}\text { Root } \\
\text { Length }(\mathrm{cm})\end{array}$ & $\begin{array}{c}\text { Shoot } \\
\text { Length }(\mathrm{cm})\end{array}$ & & $\begin{array}{c}\text { Root } \\
\text { Length }(\mathrm{cm})\end{array}$ & $\begin{array}{c}\text { Shoot } \\
\text { Length }(\mathrm{cm})\end{array}$ & \\
\hline 1 & 7.0 & 3.6 & 0.51 & 8.5 & 5.7 & 0.67 \\
\hline 2 & 6.3 & 5.0 & 0.79 & 8.0 & 5.0 & 0.62 \\
\hline 3 & 9.1 & 5.5 & 0.6 & 9.5 & 7.0 & 0.73 \\
\hline 4 & 9.0 & 5.7 & 0.63 & 8.0 & 5.0 & 0.62 \\
\hline 5 & 4.5 & 3.0 & 0.66 & 8.5 & 4.0 & 0.47 \\
\hline 6 & 4.0 & 4.0 & 1.0 & 5.1 & 4.3 & 0.84 \\
\hline 7 & 3.0 & 5.0 & 1.6 & 6.5 & 4.1 & 0.63 \\
\hline 8 & 1.0 & 3.5 & 3.5 & 7.0 & 5.0 & 1.4 \\
\hline 9 & 2.0 & 4.0 & 2.0 & 0.5 & 1.0 & 2.0 \\
\hline 10 & - & - & - & - & - & - \\
\hline
\end{tabular}

TABLE-12 : Root Shoot length of grown Mustard Seedlings: Date: 26/01/20

\begin{tabular}{|c|c|c|c|c|c|c|}
\hline \multirow[t]{2}{*}{ Sr. No. } & \multicolumn{2}{|c|}{ Algae 1} & \multirow[t]{2}{*}{ Avrg. } & \multicolumn{2}{|c|}{ Algae 2} & \multirow[t]{2}{*}{ Avrg. } \\
\hline & $\begin{array}{c}\text { Root } \\
\text { Length }(\mathrm{cm})\end{array}$ & $\begin{array}{c}\text { Shoot } \\
\text { Length }(\mathrm{cm})\end{array}$ & & $\begin{array}{c}\text { Root } \\
\text { Length }(\mathrm{cm})\end{array}$ & $\begin{array}{c}\text { Shoot } \\
\text { Length }(\mathrm{cm})\end{array}$ & \\
\hline 1 & 9.5 & 5.0 & 0.52 & 6.0 & 5.0 & 0.83 \\
\hline 2 & 5.0 & 4.8 & 0.96 & 4.5 & 8.2 & 1.82 \\
\hline 3 & 7.4 & 4.0 & 0.54 & 6.0 & 2.5 & 0.41 \\
\hline 4 & 3.5 & 6.3 & 1.8 & 7.9 & 4.0 & 0.50 \\
\hline 5 & 1.2 & 4.0 & 3.33 & 7.5 & 5.0 & 0.66 \\
\hline 6 & 2.0 & 5.0 & 2.5 & 13.0 & 6.0 & 0.46 \\
\hline 7 & - & - & - & 7.2 & 5.3 & 0.73 \\
\hline 8 & - & - & - & 8.8 & 4.7 & 0.53 \\
\hline 9 & - & - & - & 1.5 & 6.0 & 4.0 \\
\hline 10 & - & - & - & 1.2 & 4.0 & 3.33 \\
\hline
\end{tabular}



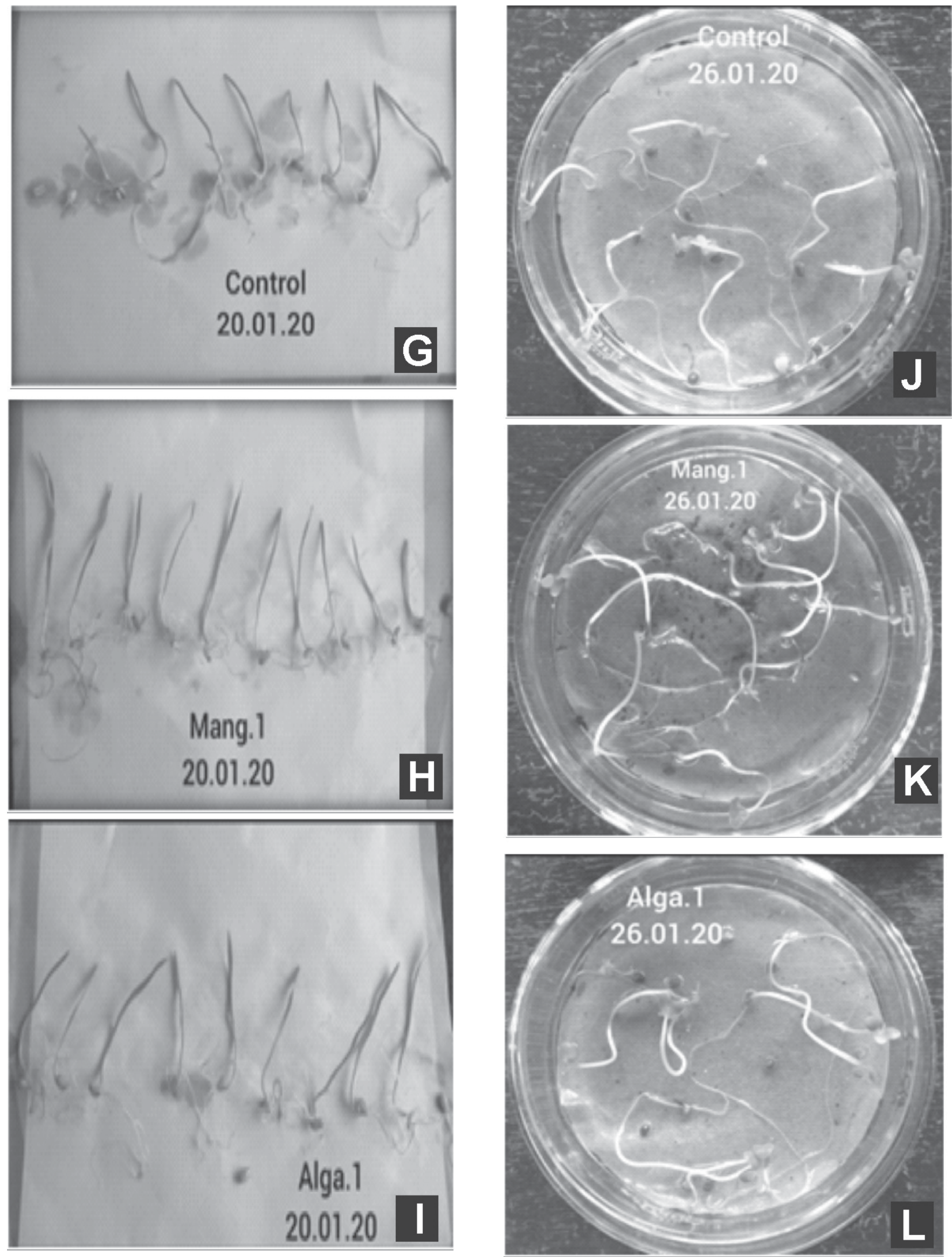

Fig.3 G-I : Grown up wheat seedlings

Fig. 4 J-L: Grown up mustard seedling. 


\section{Observations}

The first germination was noted in the aqueous mangrove leaf extract treated sets of wheat seeds on second day of sowing while in case of Mustard seeds on third day of sowing.

\section{Result and Discussion}

The wheat and mustard seeds were treated with aqueous mangrove (R.mucronata) leaf extract. Its activity was compared with aqueous seaweed (Sargassum) extract which is used commercially in organic farming as a biofertilizer. The seeds treated with mangrove leaf extract had shown promising effect on seed germination, the germination rate was quite high as well as the growth of seedlings was enhanced. Aqueous mangrove treated seeds shown longer shoot and root length as compared to water treated and seaweed extract treated seeds. During the investigation we also found that control set and seaweed extract treated sets were susceptible to fungal infection while the sets treated with mangrove leaf extract were healthy.
As the mangrove leaves containing Gibberellic acid (GA), a plant growth regulator, they hasten seed germination. Along with GA mangrove leaves also containing cytokinins and auxins. The auxins and cytokinins are responsible for enhancing root and shoot growth respectively ${ }^{6}$.

\section{Conclusion}

The seeds which were treated with aqueous mangrove leaf extract showed higher percentage of seed germination as well as long root and shoot as compared to water and algal extract treated seeds. This is due to the fact that mangrove ( $R$. mucronata) leaf extract contains inorganic nutrients like $\mathrm{Na}, \mathrm{K}, \mathrm{P}, \mathrm{Mn}, \mathrm{Mg}$ etc. as well as all the essential PGRs which are required for plant growth. Thus it has potential to be used as a biofertilizer in agriculture and it will be a good substitute to replace chemical fertilizers.

The Sargassum wightii was used as biofertilizer for growing crops like Abelmoschus ${ }^{5}$ and on Arachis hypogeal?.

\section{References}

1. Cerutti A., Jauneau A, Laufs P, Leonhardt N, Schatta M, Berthome R, Routaboul JM. Mangroves in the leaves: Anatomy, physiology and immunity of epithemal hydathodes. ; ARjatc.2019; 14:5

2. Erulan V, Soundarapandian P, Thirumaran G, Ananthan G. Studies on the effect of Sargassum polycystum (C. agardh) extract on the growth and biochemical composition of Cajanus cajan (L.)Mill sp. Am-Euras. J. Agric. \& Environ. Sci. 2009; 6 (4):392-399.

3. Fransworth Elizabeth. Hormones and shifting ecology throughout plant development. Ecology. 2004; 85(1): 5-15

4. Jie Wang. Analysis of ABA, GA3 in reproductive organs of Bruguiera gymnorrhiza. .J. Xiamen University. 2008; 05: 33-37.

5. Jothinayagi N, Anbazhagan C. Effect of Seaweed liquid fertilizer of Sargassum wightiion the growth and biochemical characteristics Aobelmoschus esculentus (L.) Medikus. Rec Rec Sci Tach. 2009; 1: 155-158.

6. Mirian E, Caldas L. Seed dormancy and germination as concurrent processes. R. Bra. Fisiol. Veg. 2000; 12: 85104.

7. Sekeran S, Rengasamy R. Significance of Seaweed liquid fertilizer for minimizing chemicak fertilizers and improving yield of Arachis hypogaea under field trail. Rec Rec Sci Tech. 2010; 2: 73-80.

8. Thangavelu Boopathi. Characterization of IAA production by the mangrove. J. PGR.. 2013; 32(4): 758-766.

9. Yemul N. B. and Sayekar H. A. M., The effect of Rhizophora mucronata Lam. (Mangrove) leaves extract on the germination of Oryza sativa L. seeds. Contemporary Research In India. 2016. 2. 